\author{
Review Article
}

\title{
Counseling Model Based on Gusjigang Culture: Conceptual Framework of Counseling Model Based on Local Wisdoms in Kudus
}

\author{
Edris Zamroni
}

Universitas Muria Kudus, Indonesia

edris.zamroni@umk.ac.id

\begin{abstract}
This article discusses the developing of conceptual framework of gusjigang counseling model as a manifestation of local wisdoms hold by the people of Kudus regency. Gusjigang is a philosophy of life taught by Sunan Kudus (one of the nine Java island's first Muslim missionaries) which teaches men to have a good behavior (gus), to be good at reciting Koran (ji) as well as trading (gang). Gusjigang counseling model is close to Islamic counseling nuance which sets out the Islamic values of Kudus people who have been widely known as religious people. The goals of this counseling model are to develop men's virtuous characters, scientific and systematic thoughts, and improve persistence, creativity, innovativeness to survive.
\end{abstract}

Keywords: counseling model; gusjigang; local wisdoms in kudus

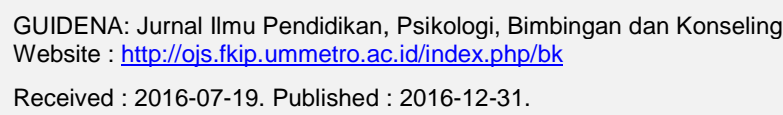

\section{INTRODUCTION}

Guidance and counseling is a discipline based on psychology which was developed by the prior experts. C. Beers in 1908 started a movement of mental health as the answer to the rapid development of society which caused some people to suffer from psychological distress (Tyler, 1986 in Suherman, 2009). In 1909, therefore, Frank Pearson (Munandir, 1997) pioneered guidance and counseling service through a career guidance service to answer the needs of the right people in the right position during the industrial revolution in The United States. The discipline of guidance and counseling has been developed and combined with psychological discipline in every service given to the society.
Most of psychological discipline used as the reference in giving therapeutic service to the counselor was originally brought by experts from different background of culture, personal life and life experience. The believes of the inventors of psychological theory highly influenced their perceptions on human beings as a whole, how they perceived certain problem and treated the clients when giving therapeutic service (Feist and Feist, 2012). However, there are still some possibilities for a doubt to occur in applying a theory of counseling because the counselor's beliefs are far different from what is on theory. In line with this, Sutoyo (2009) explained that the truth within a theory based on science is tentative. If it is based on philosophy, it is speculative and when it is 
based on vision from God, it becomes absolute. Referring to the idea, it is logical when in certain circumstances and condition, the discipline of guidance and counseling becomes helpless in explaining various problems occurred in the area.

As an "imported" discipline from countries having different culture from Indonesia, it needs some acculturation and assimilation of the discipline combined with the needs and socio-cultural condition in Indonesia. Prayitno (2012) stated that the identity of guidance and counseling in Indonesia has been established in Act of Republic of Indonesia No. 20 of 2003 that counselors are faculty members who have special expertise in giving counseling service in educational setting. However, it is hard to find the counselors who were nurtured by Indonesian philosophy of life. Thus, it needs a developing of a counseling service which is really based on Indonesian culture, values and believes.

Surya (2013) explained that by living the fact that Indonesia is a multi-ethnic and multicultural nation, the counselors in Indonesia will deal with clients who have various ethnic and cultural background as well. That will obviously affect the process, the strategy and the result of the counseling service. Thus, the values of certain culture should be taken as a main consideration in conducting a counseling in the multi-ethnic and multi-cultural society in this modern and globalization era. Every culture has its own distinctive values and the culture itself cannot be separated from the Indonesian culture in general, which has a number of local wisdoms. The diversity of culture should not basically be seen as barriers but it should be seen as reference and guidance in carrying out guidance and counseling in Indonesia.

Since every individual is closely attached to his cultural identity in certain ethnic group, the counseling service should be flexible by adjusting the treatment with the personal beliefs of each client. By applying this, there is no chance for the counselor to make a barrier during the counseling service. It does not mean that the counselor is being racist because his action is not based on certain stereotype on certain ethnic group, but this is more like an adaptive effort of the counselor in giving the counseling which best suits the needs and personal beliefs of the client.

One of the Indonesian local wisdoms is Gusjigang. Gusjigang is a philosophy of life, a legacy of Sunan Kudus which grows, develops and becomes some beliefs of the people in Kudus. Gusjigang is an acronym from the word Gus (Bagus - having good behavior), Ji (Ngaji -good at reciting the Qur'an) and Gang (Dagang - good at trading). As one of the nine first Muslim missionaries in Javanese island, Sunan Kudus was known as a wealthy trader who was also virtuous and having deep knowledge of Islam. He became the role model of his people. The developing of gusjigang counseling model is an effort to build an idenity in counseling through counseling discipline acculturation of the West Countries with local cultural and scientific understanding based on local wisdoms living in Kudus.

\section{DISCUSSION}

The infusion of gusjigang values in counseling service is a big dream in developing counseling model rooted from Indonesian culture. Gusjigang is a philosophy of life of the people in Kudus as a local wisdoms and a local culture as well as moral values taught by Sunan Kudus which is nowadays being forgotten by the people especially the young ones (Zamhuri, 2011). Gusjigang philosophy taught by Sunan Kudus is an acronym from the words Gus (Bagus - having good behavior), Ji (Ngaji good at reciting the Qur'an) and Gang (Dagang -good at trading). This aged more than 700 year philosophy lasts until now in everyday life of Kudus people and becomes a social source from Kudus people (Ismaya, 2013). Bagus is a representation of noble moral character which should be owned by society concerning the horizontal relation among them and vertical relation between them and Allah The Almighty. Ngaji is not narrowly meant by simply good at reading or reciting Qur'an but it is widely understood by always learning dynamic of life using different discipline perspective to get the answers for every problem with different alternatives as well as giving contribution to the development of science and knowledge for mankind. Dagang is seen as entrepreneurship spirit which the people of Kudus should have in order to be creative and innovative in searching 
sources of income and maintaining the existence of lives materially. Gusjigang counseling model is aimed at helping the clients to have independent lives materially and immaterially, to have emotional maturity by being able to explore every problem of life using different perspectives and to have the chance to reach optimum and prosperous lives. The counseling does not only have orientation in local and actual problems but also give contribution in planning and building up bright future.

\section{Rationale}

Indonesia is a nation which has various tribes. The diversity is proven by the existence of many islands spreading from Sabang until Merauke with population more than two hundred million lives inhabiting those islands. The population also inhabits some areas which have various geographical conditions from mountainous area, wood periphery, costal area, lowlands, rural until urban area. Such condition represents the diverse tribes who live in. Every tribe has its own culture as a result of their creativity. Indonesian people consists of diverse tribes. This tribe diversity causes diverse cultures. Every tribe has a distinctive culture from the others' culture. The diversity in the people is a priceless national asset which can unite Indonesia as a nation. It is a power to build the nation to grow as a big nation. This nation should not discriminate certain tribe or ethnic group from another because it can cause dispute and chaos among the society.

Mankind is called a civilized creature which means that he is always using his intelligence to create happiness because making a happy life is something virtuous, righteous and honest. Therefore, only human being who is always trying to establish goodness, rightness, and justice in life can be considered as a civilized individual. Culture is one way of life developed and shared together by a group of people and inherited from one generation to the next generations. Culture is formed by numerous complex elements including religious system, politic, customs, languages, tools, clothes, buildings, and arts. Being cultural, human beings are expected to be able to fulfill their needs and resolve the challenges of life. Human beings are different from God's other creatures. They live according to the norms and values established in their surroundings. Consequently, they should socialize and follow the norms and values socialized by the people before them. People who disobey and violate those rules will be considered as savages or barbarians. Along with the development of knowledge and civilization, occurs culture evolution which causes some problematic issues waiting us to examine and find the best solutions.

Having culture is considered as humans' strength compared with the other creatures. Human beings are the most perfect creature having some roles and responsibilities to run the earth. Therefore, they should have what they need to carry out their duties on earth including the ethical and moral responsibilities, to do virtues, rightness, justice and responsibilities to be worth for humanity. Moreover, human beings should also use their intellectual to create happiness to all God's creatures.

In relation with the environment, human beings are living organisms. Their characters are influenced by their environment. Moreover, it can be extremely stated that every individual comes from an environment, both vertical environment (genetic and tradition) and horizontal environment (geographic, physic, social) as well as historical environment. When a baby was born, he felt a different temperature and losing energy which caused him to cry, hence he wanted to lessen the difference and replace the losing. Starting from this moment, occurred a basic belief that every individual is blessed with senses, to discriminate and to survive. To survive, an individual needs something. Whilst that something comes from the environment.

A problem which occurs in humans' life is frequently caused by some frictions among society personally or between society and environment including the frictions between society and customs, traditions, local wisdoms shared by the people in the society. For instance, a person who is in deep grief because he feels that he is the poorest of all, might perceive that the people around him are better or richer. Consequently, it would make him ambitious "to catch up" the people around him. In counseling service context, placing an individual as a civilized or cultural person is important. Culture awareness of the counselors 
about different values between them and the clients should be sharpen in order to make the counseling service runs effectively.

Counseling service based on local wisdoms is a counseling process which is established by the basis of sociological and psychological condition and some local wisdoms in every ethnic group. In a study conducted by Prue and Voss (2014) on Mestizo society in Amazon who had strong culture called ayhuasca, found that there was a cultural connection in a counseling process relation which gave therapeutic effect on drug abuses. That study proven that local wisdoms which are internalized in every individual can give therapeutic effect, hence it can be adopted in a counseling service context.

In a different culture context, Hwang (2009) describes that the weakness of Psychology from west countries encourages the development of multi-cultural psychology which investigates specifically cultural richness in counseling service. Hwang conducted a study in Confucius community which is very popular in China. The study revealed (a) some conflicts of values between Confucian heritage and individualism brought by The West in globalization era; (b) psychometric approach to measure the conflicts in collectivism; (c) situational counseling model, self coordination for Chinese clients to solve the conflict between individuals; and (d) the implications of psychotherapy from some self empowerments from the cultural traditions of Confucianism, Taoism, and Buddhism.

In Chinese culture context, Leung and Chen (2009) also conducted a study to investigate some weaknesses of psychology from The West to resolve some problems in Chinese community. The study focused on the cross-culture weaknesses and the psychological counseling application was discussed using multi-cultural counseling literatures and competencies as its illustration. The writers explained the scope and characteristic of custom psychological counseling and discussed how indigenization of the psychological counseling could be carried out to some Chinese communities in Asia both on national and local level. Meanwhile, some multicultural issues in Chinese communities in Asia are identified as the potential focus of study.
In the previous year, Crump (2001) studied some possibilities of local assets in educational field and their implication on career counseling. Crump tried to study some local wisdoms of the Aborigines and people of Torres Strait Islands. The results of the study allowed every values believed by the Aborigines could be generalized as national treasure to solve various problems faced by the indigenous people of Australia.

Cultural context in counseling service has also been done in Indonesian cultural frame. Prayitno (1986) developed Pancawaskita counseling as his determination in internalizing human's five power in counseling service. Religious values which seem lack in some western counseling styles have encouraged Prayitno to develop a religious counseling model as the character of Indonesian cultures which based on Pancasila (Indonesian Five Principles).

Related to the context of local wisdoms, Petrus (2012) developed a group counseling model based on the culture called Hibua Lamo. This culture is full of togetherness, kinship and equality values to appreciate each other. Some values contained in Hibua Lamo are $O$ dora which means love, it has a deep meaning to be the basis for loving others and ourselves; $O$ hayangi which means compassion to help each other; $O$ baliara which means care about others, support others, help others to establish harmonious situation; $O$ adili which means justice and equal rights. Those values are main elements of our society. In connection to those mentioned values, there is a special way of life among the society which always places the relation among people in the highest place through a philosophy named "Ngone O Ria Dodoto" (one mother or blood relation). This philosophy has a deep meaning which states that everyone in this world has equal rights with no difference. Those values have been covered in etiquettes in our society both communally and individually.

Indonesian culture diversity allows to be developed into some counseling models which are based on local wisdoms. Each culture has its special characteristics. As Sundanese Buhun people who have "Tri Tangtu", Javanese people who are known to have "Memayu Hayuning Bawana, Ambrasta dur Hangkara" and other philosophy of life which are owned by 
other ethnical groups, Kudus people have a philosophy of life called GUSJIGANG which has been more than 700 years being deep rooted as a cultural product taught by Sunan Kudus.

Gusjigang, a philosophy taught by Sunan Kudus, is an acronym from the words bagus, ngaji, and dagang. It has been more than 700 years old which is still remain in the daily life of people of Kudus and it is also a social asset of Kudus people (Ismaya, 2013). Gusjigang philosophy is a behavioral philosophy of life applied daily.

Gusjigang philosophy taught by Sunan Kudus, is an acronym from the words Gus (Bagus - having good behavior), Ji (Ngaji good at reciting the Qur'an) and Gang (Dagang - good at trading). This philosophy is more than 700 years old, until now it is still attached to the daily life of the people of Kudus and it becomes social assets for the people (Ismaya, 2013). Gusjigang philosophy is a daily life manual which is exalted and strongly believed by the people of Kudus. Even after early 190os, Gusjigang became one of the cultural requirements obliged to the groom to be able to marry a girl from Kudus, especially Kudus Kulon area. It resulted a phenomenon that the people of Kudus would not marry their daughters with men whose job was civil servant. In that time, the people perceived that a civil servant earned less than an entrepreneur or a merchant did. This perception was the realization of Gusjigang philosophy related to the concept of welfare of the people of Kudus. In its time, Gusjigang philosophy became a daily work ethic of the people of Kudus and had an important role in affecting the point of view and advancement of the people of Kudus. Gusjigang philosophy taught by Sunan Kudus actually teaches that trading and running business reflect our religious service to God (Allah The Almighty) which can lead us into happiness in this world and hereafter. By trading or running business, it can give benefit not only to the doer but also to others and surroundings (Utaminingsih and Ismaya, 2014).

Gusjigang is an ideal condition of an individual which is represented by three words Gus (Bagus - having good behavior), Ji (Ngaji - good at reciting the Qur'an) and Gang (Dagang - good at trading). Bagus reflects good characters which should be possessed by the society regarding to horizontal relation among people and vertical relation between a man and His Creator. Ngaji is not only meant narrowly as reciting/reading Qur'an but it is more widely meant to continuously learn every dynamic in life with different perspectives to figure out the solution of every problem with some alternatives and give knowledge and information contribution to humanity. Dagang is meant by a spirit of entrepreneurship which should be owned by the people of Kudus to creatively and innovatively find the source of income to maintain their life existence. Gusjigang counseling is aimed at helping the clients to have independent life both materially and immaterially, to get psychological maturity in figuring out problems and life challenges with different perspectives and to get optimum progress of life and welfare. The counseling is not only oriented in present and current problems but also contributed to the planning and organizing brighter future.

Said (2013) stated that Gusjigang philosophy has three core values, they are:

a. Virtuous: The word "gus" is the acronym of the word "Bagus" which is a reflection of an ideal person who has to possess good characters or virtuous in relation among society and with Allah The Almighty.

b. Scientific Tradition: The word " $j i$ " is the acronym of the word "Ngaji" which means broad knowledge owned by every individual either religious knowledge or general knowledge to get prosperous life. Sunan Kudus has been the example for he is known as waliyyul ilmi.

c. Enterpreneurship: The word "gang" is the acronym of the word "Dagang" which means values and skills possessed by every individual to maintain his life existence using his creativity and independence in earning money to support his life.

Based on the mentioned ideas, it feels essential to develop Gusjigang counseling model to advance an ideal condition of life in accordance to the philosophy taught by Sunan Kudus, with the hope that the client can be an individual who has virtue, scientific way of thinking, creativity and independence in life. 


\section{Key Concepts and Views of Problem Behavior}

Key concepts about counseling views with Gusjigang approach to a whole figure of a man are:

1. A man is God's most perfect creation who has dispositions of physical, spiritual and religious faith. Those three dispositions are integrated each other and they also control each other to keep the balance condition in life.

2. A man is created with pure dispositions, having righteousness and virtuous potentials rather than bad ones. The emergence of bad behavior is more caused by the man himself who less keep the faith which causes some diseases to attack the heart and make him move away from the expected and ideal line.

3. The man's potential to think scientifically and systematically is mostly because human is created by God with both intelligence and passion which make him always want to know, try, possess and control. If those potentials are well maintained, they will give much benefits to the man and his surroundings.

4. A man is basically a persistent and creative creature. If we learn the history, from the emergence of Darwin theory, human is always growing their mind and civilization. It proves that human always think creatively and innovatively to survive, to be wealthy and secured. However, this potential will only optimally grow if it is in suitable environment. The appropriate environment can improve the creativity and the ability to innovate and survive in facing numerous problems.

Based on those views about human above, basically certain behavior is regarded wrong when the human cannot show good characters to others, tend to be evil and violate the norms. Problem behaviors also happen when the human cannot think scientifically, systematically, and holistically, and tend to be too dogmatic in viewing certain problem or issue. The last is that the problem behavior happen when the human cannot think creatively, innovatively, and ten to give up easily in dealing with problems and fulfilling the needs in life.

\section{The Essence of Gusjigang Counseling}

The essence of Gusjigang counseling is to help an individual to learn to develop virtuous characters in behaving and taking action, the ability to think systematically and holistically, and persistence, creativity and ability to innovate to face the challenges of life as well as to maintain his existence by empowering human's religious values, learning and putting in practice his knowledge so that his entire essence as a human can run and function optimally. In the end, it is expected that the client will have a happy life through the counseling given.

\section{The Goals of The Counseling}

The final goals of applying this counseling model is to achieve wealthy of life with some basic skills owned by a civilized society and each individual can develop and grow fully as a whole human being who has virtue and broad knowledge, and who can survive in any condition. In other words, it leads the individual to be able to build harmonious relationship with others as well as with God, to have broad knowledge, and to be able to survive using all his skills to earn money to fulfill the needs in any condition.

Short term goals of this counseling model for the clients are:

1. They can act and behave pleasantly with others and always obey and comply with the rules and tenets from Allah The Almighty.

2. They have curiosity so that they are eager to learn new things.

3. They can think holistically so that they can perceive certain problem from different perspectives in accordance with their knowledge.

4. They can think creatively and innovatively in seeing chances and challenges before them.

5. They can live independently as individuals who can fulfill needs in life materially and immaterially.

6. They can perform as religious figure.

\section{Counseling Principles}

During the counseling practice, a counselor has to perform standard ethics which are based on the professional counseling practice principles by following norms and culture values (Rowley and Mc Donald, 2001). Referring to the idea, the followings are 
principles which have to be followed in giving Gusjigang counseling model:

\section{Counseling Basic Principle}

Men are created by Allah The Almighty in the most perfect form compared to other creatures. Men are blessed with the ability to create, to feel, to invent and to have will so that they can initiate something, consider the good and the bad, innovate to make something and have will to do and not to do something. In culture context, men are the main actor who create, operate and maintain certain culture. The culture main substances are knowledge, point of views, belief, perceptions, and culture ethics. The three most important elements are knowledge, values and viewpoint. Therefore, to be culture people, we have to own knowledge, technology, culture and industrialization as well as virtuous characters as integrated and synergetic entity. In giving counseling, the clients should be directed gradually to be individuals who are independent, creative and virtuous.

\section{Principles Concerning the Counselor}

The counselor was chosen based on the qualification of experience and the ability to be the role model of having virtuous characters, determination, creativity and innovative action, independency, and success in life. The counselor should also have culture awareness in order to be responsive to see some potential barrier caused by different cultures and have basic knowledge in giving counseling.

\section{Principles Concerning the Client}

In giving counseling, it needs to always take into account that men are created by Allah The Almighty with many blessings and diversity from one with another. Thus, men should keep trying to optimize their potentials and appreciate the differences for they are assets to help men survive, to keep encouraging to have good relationship with others, to be creative, to keep learning and studying and always believe that Allah The Almighty will always ease the way of the people who have faith in Him.

\section{Principles Concerning the Counseling Service}

The first thing to believe is that aqidah tauhid will strengthen men's faith and belief so that they will always believe that every good deed will bring something good in return and vice versa. With this belief, the client is encouraged to believe that if men wish to think and try, they will gain successful and wealthy in life. The results depend on the effort supported by prayers to God. Basically, every man has the ability to solve every problem in life if only he can make use of his knowledge to perceive the problem in different perspectives that many solutions will be obtained for the problem before him. Values and viewpoints of the client should also affect the way the solve the problem thus the counselor cannot force his own values to the client for the client has different belief, viewpoints of life and values.

\section{Steps in GusjigangCounseling Model}

Similar with the previous counseling models, Gusjigang counseling is developed based on the available steps and models. In this case, Gusjigang counseling is more colored with trait and factor counseling approach. The steps of the counseling being developed are:

\section{Analysis on the Cause of the Problem}

The first step is to analyze the cause of the problem of the client. Problem analysis is based on some possible causes of the problem which threaten client's happiness based on ideal condition which is expected by Gusjigang philosophy. The horizontal problems emerging between the client and his surrounding may be due to the incapability of the client in making good relation which is caused by his own bad characters. Besides, as a religious person, the client may be less thankful to God so God gives him troubles as a reminder for him.

In another hand, that the client is less competent in solving his problems is because the client does not have much scientific thinking to see the problem in different perspectives. In a cornered situation in facing a problem, the client frequently becomes irrational and cannot think clearly which eventually makes the 
problem bigger and difficult to solve. A problem related to financial condition is possibly because the client is less creative and innovative to find sources of income to fulfill his daily needs.

\section{Analysis on Effects and the Assumptions of Techniques Applied}

Similar to trait and factor counseling, Gusjigang counseling views that bad behaviors will bring bad effects on the client if they are left unsolved. The client's incapability to manage himself to do virtuous, to think scientifically and strategically, to think creatively, and live independently will give obstructions in life and disturb the client's optimum development.

\section{The Application of the Counseling techniques}

Counseling techniques applied are:

\section{a. Modelling}

Giving a role model is one technique which is recommended mostly in this counseling. The main role figure is Sunan Kudus as waliyyul ilmi who has religious, military, and wide-ranging knowledge, has good characters as a religious leader, and becomes a wealthy merchant who likes to give charity to his religious followers and the people around him. Ibrahim and Dykeman (2011) stated that most of the Moslem population in America and any other parts of the world really yearn the ideal figure of the Prophet Muhammad as the role model for all Moslems to live their lives. This means that showing the good example is more effective to use to the moslem population in Indonesia.

\section{b. Cognitive Restructuring}

Cognitive reconstruction is a technique which is mostly used to arouse rational thinking. Problems caused by the inability to think scientifically can be corrected through reconstruct the way of thinking in order to think more systematically in dealing certain problem (Collins, Arthur dan Wiley, 2010).

\section{c. Reinforcement}

The next technique is reinforcement. Reinforcement is given to rise confidence and to encourage the clients that actually they have potential to think creatively, innovatively and to live independently if they can rearrange their lives and to think scientifically and systematically as well as to show good behaviors toward others and God so that they can be successful and wealth. Sutoyo (2009) stated that counseling with Islamic atmosphere will be more effective if it is conducted firstly by compelling the client about the essence of human as a God's creation who has to obey their Creator and about the God's promises to ease the way of the people who are in His Way. Finally, the condition will encourage the clients to understand and perform their belief and to encourage the clients to be iman, islam and ikhsan.

\section{Evaluation}

To evaluate the results of the counseling can be done by observing some changes in client's attitudes in everyday life including characters and individual behaviors, habits and the ability to think and conduct scientific study, persistence, creativity, innovation and individual independence in maintaining and fulfilling his needs.

\section{Follow-up}

After counseling session completed, the counselor needs to arrange some preventive, conservative, and restorative actions. The potential aspects also needs to be taken into account for emerging in the next counseling sessions.

\section{Counseling atmosphere}

The main role of a counselor in this approach is as a reminder and a role model for the clients. The built atmosphere is a home-like atmosphere which allows the counselor to remind the clients of their actions which are inappropriate with the concept of Gusjigang philosophy. Moreover, the counselor should be able to put himself as a role model for the clients, at least in how to think critically, to be determined in life, and to think systematically to solve life's problematic problems. The role as a reminder is an Islamic tenet which sees an 
individual to have different level of faith that is why s/he needs the help from the environment to nurture, to cherish and finally it can be flourished. Furthermore, Allah The Almighty has sent His prophet with some guidance of life in the form of Qur'an and Hadists as a reminder and a guidance of life. Consequently, the counselor is only to remind and to become a role model for the clients for being in the right path according to Allah's guidance through Qur'an and Hadists.

In general, the counselor has to keep being next to the clients for them to be in the right path which is in accordance to what has been taught by Sunan Kudus and shared by all the people of Kudus as one philosophy and way of everyday life.

\section{CONCLUSION}

Based on the explanations above, it can be concluded that Gusjigang counseling is a model of counseling developed on the basis of local wisdoms in Kudus which aims at developing virtuous characters, increasing the ability to think systematically and scientifically as well as improving determination, creativity, and ability to innovate to be able survive. Gusjigang philosophy is a lesson taught by Sunan Kudus which tells that human beings should have good characters, should be good at reciting Qur'an and should be good at trading as well. It still needs deeper studies to figure out the key concept about a whole figure based on Kudus local wisdoms. Recommendation; To make perfect the conceptual framework of gusjigang counseling model, it needs the participation of all parties to give their contribution in digging deeper information of the philosophy of Gusjigang taught by Sunan Kudus. Therefore, there will be a more perfect model which is ready to apply as the assets of counseling in Indonesia.

\section{REFERENCES}

Collins, S., N. Arthur, and G. W. Wiley. (2010). Enhancing Reflective Practice in Multicultural Counseling Trough Cultural Auditing. Journal of Counseling Development, 88(3), 340-347.
Crump, D. (2001). Issues in Indigenous Educational and Vocational Counseling. Australian Journal of Career Development October 2001, 10(3), 20-24.

Feist, J dan G. J. Feist. (2012). Teori Kepribadian: Theories of Personality. Jakarta: Salemba Humanika.

Hwang, K. K. (2009). The Development of Indigenous Counseling in Contemporary Confucian Communities. The Counseling Psychologist, 37(7), 930-943.

Ibrahim, F. A. and C. Dykeman. (2011). Counseling Muslims Americans: Cultural and Spiritual Assessment. Journal of Counseling and Development, 89 (4),387396.

Ismaya, E.I. (2013). Falsafah Gusjigang Sebagai Modal Sosial Membangun Masyarakat Kudus Yang Sejahtera. Disajikan dalam Seminar Internasional Ikatan Sarjana Geografi Indonesia di UGM. Yogyakarta: Universitas Gajah Mada.

Leung, S. A. and P. H. Chen. (2009). Counseling Psychology in Chinese Communities in Asia Indigenous, Multicultural, and Cross-Cultural Considerations. The Counseling Psychologist, 37(7), 944-966.

Munandir. (1997). Program Bimbingan Karir di Sekolah. Jakarta: Direktorat Jendral Pendidikan Tinggi.

Petrus, J. (2012). Model Bimbingan Kelompok Berbasis Nilai-Nilai Budaya Hibua Lamo Untuk Meningkatkan Kecerdasan Sosial Siswa. Jurnal Bimbingan Konseling, 1(2) Th. 2012.

Prayitno. (2012). Kilas Balik Sejarah Lahirnya Bimbingan dan Konseling di Indonesia. Disajikan dalam Seminar Nasional Bimbingan dan Konseling tanggal 12 Juni 2012 di Universitas Negeri Medan.

Prayitno. (1996). Konseling Pancawaskita: Kerangka Konseling Eklektik. Padang: Jurusan Bimbingan dan Konseling FIP Universitas Negeri Padang.

Prue, R. and R. W. Voss. (2014). Indigenous Healing Practice: Ayahuasca. Journal of Pastoral Care \& Counseling 68 (1).

Rowley, W and D. McDonald. (2001). Counseling and The Law: A Cross-Cultural 
Perspective. Journal of Counseling and Development, 79(4), 422-429.

Said, N. (2013). Gusjigang dan Kesinambungan Budaya Sunan Kudus: Relevansinya Bagi Pendidikan Islam Berbasis Local Genius. Jurnal Pendidikan Islam EMPIRIK, 6(2) Th. 2013 .

Suherman, U. (2009). Konseling Karir Sepanjang Rentang Kehidupan. Bandung: Sekolah Pascasarjana UPI Bandung.

Surya, M. (2013). Bimbingan Karir Berbasis Kearifan Lokal dan Nilai Keluarga: Pengembangan Karir Peserta Didik Melalui Pelayanan Konseling Bermartabat Dalam Membentuk Karakter Budaya Antar Bangsa Dalam Masyarakat Multikultural dan Modern. Makalah dalam Kongres XII dan Konvensi Internasional ABKIN, diselenggarakan tanggal 14-16 November 2013 di Hotel ASTON Denpasar Bali.

Sutoyo, A. (2009). Bimbingan dan Konseling Islami Teori dan Praktik. Semarang: CV. Widya Karya.

Undang-Undang Nomor 20 Tahun 2003 Tentang Sistem Pendidikan Nasional. Jakarta: Kementerian Sekretaris Negara.

Utaminingsih, S. and E. A. Ismaya. (2014). Moral Education Evaluation Model Based on Local Culture "GUSJIGANG" Involving Three Components. Ringkasan Penelitian. Kudus: Lembaga Penelitian Universitas Muria Kudus.

Zamhuri. (2011). Sunan Muria dan Sunan Kudus: Prinsip Hidup Dalam Membangun Karakter Bangsa. Kudus: Badan Penerbit Universitas Muria Kudus. 